\title{
PENGEMBANGAN BAHAN AJAR TEMATIK TERPADU DENGAN MODEL COOPERATIVE SCRIPT DI KELAS IV SEKOLAH DASAR
}

\author{
Dina Dahliana \\ STAI Solok Nan Indah \\ dina_dahliana@staisni.ac.id \\ Remuti \\ STKIP Adzkia \\ remuti97@gmail.com
}

\begin{abstract}
Teachers are very instrumental in developing effective teaching materials to encourage the progress of students in learning. Meanwhile, the existing teaching materials still need improvements because there are several errors such as paragraphs in the reading text that are not aligned left-right, errors in capital letters. Therefore, to solve this problem, it is necessary to find a solution in the form of developing integrated thematic teaching materials based on the cooperative script model for grade IV elementary school students. This study aims to produce valid teaching materials. This type of research is development research using the 4-D model (four D model). This model consists of four stages, namely define, design, develop and disseminate. The results showed that the integrated thematic teaching materials using the cooperative script model developed obtained the validity percentage of teaching materials was $87.5 \%$ (material) with a very valid category, $75 \%$ (language) with a valid category, and $81.8 \%$ (design) with very valid category.
\end{abstract}

Keywords: Teaching Material Development, Integrated Thematic, Cooperative Script Model.

\begin{abstract}
Abstrak
Guru sangat berperan dalam mengembangkan bahan ajar yang efektif untuk mendorong kemajuan peserta didik dalam belajar. Sementara itu bahan ajar yang ada masih perlu perbaikan-perbaikan karena terdapat beberapa kesalahan seperti paragraf dalam teks bacaan belum rata kiri-kanan, kesalahan penulisan huruf kapital. Oleh sebab itu, untuk mengatasi permasalahan tersebut, perlu dicari solusi berupa pengembangan bahan ajar tematik terpadu berbasis model cooperative script untuk siswa kelas IV Sekolah Dasar. Penelitian ini bertujuan untuk menghasilkan bahan ajar yang valid. Jenis penelitian yang digunakan adalah penelitian pengembangan dengan menggunakan model 4-D (four D model). Model ini terdiri dari empat tahap yaitu pendefinisian (define), perancangan (design), pengembangan (develop), dan penyebaran (desseminate). Hasil penelitian menunjukkan bahwa bahan ajar tematik terpadu menggunakan model cooperative script yang dikembangkan memperoleh persentase kevalidan bahan ajar adalah 87,5\% (materi) dengan kategori sangat valid, $75 \%$ (bahasa) dengan kategori valid, dan 81,8\% (desain) dengan kategori sangat valid.
\end{abstract}

Kata Kunci: Pengembangan Bahan Ajar, Tematik Terpadu, Model Cooperative Script.

Program Studi Pendidikan Guru Madrasah Ibtidaiyah

STAI Al-Azhar Menganti Gresik, Indonesia

\section{Pendahuluan}

Dalam kurikulum 2013 kegiatan pembelajaran di Sekolah Dasar kelas I sampai VI dilakukan dengan menggunakan pembelajaran tematik terpadu. Pemerintah merancang pembelajaran abad 21 melalui kurikulum 2013 yang berbasis pada peserta didik. Pendidik sebagai tangan kanan dari pemerintah di sekolah-sekolah menerapkan kemampuan 4C (Critical Thinking, Communicaion, Callaboration, Creativity). Menurut Rusman (2015 : 139) 
pembelajaran tematik terpadu bermakna karena peserta didik akan memahami konsep-konsep yang mereka pelajari melalui pengalaman langsung dan menghubungkannya dengan konsep lain yang telah dipahami. Proses pembelajaran tematik terpadu di Sekolah Dasar lebih bergantung pada kondisi sekolah, baik yang menyangkut metode maupun bahan ajar. Secara umum pembelajaran di Sekolah Dasar masih disampaikan secara konvensional, masih didominasi ceramah walaupun kadang ada yang menggunakan diskusi, hanya sedikit sekolah yang menetapkan metode pendekatan ilmiah seperti praktikum ataupun demonstrasi. Semua itu terkendala pada keterbatasan bahan ajar, apalagi Sekolah Dasar di daerah terpencil. Keadaan ini membuat pendidik Sekolah Dasar mengandalkan sepenuhnya pada buku paket yang bersumber dari Dinas Pendidikan Nasional atau Departemen Pendidikan, dan buku teks lainnya.

Bahan ajar yang digunakan tidak dirancang oleh pendidik sesuai dengan kebutuhan dan karakteristik peserta didik. Pendidik hanya mengandalkan penggunaan buku-buku pelajaran tanpa menganalisis terlebih dahulu apakah buku tersebut sesuai dengan Kompetensi Dasar yang harus dikuasai oleh peserta didik. Kreativitas maupun pemahaman pendidik terhadap perencanaan bahan ajar masih kurang, ini terlihat ketika mengajar pendidik tidak membuat bahan ajar sendiri sehingga proses pembelajaran tidak berjalan secara efektif. Depdiknas (2006) menjelaskan bahwa bahan ajar yaitu segala bentuk bahan yang digunakan untukmembantu guru dalam melaksanakan kegiatan belajar mengajar di kelas, baik berupa

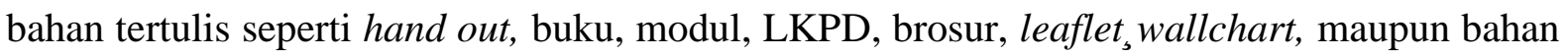
tidak tertulis seperti video/ film, VCD, radio, kaset, CD interaktif berbasis computer dan internet. National Centre for Competency Based Training (Prastowo, 2011) menjelaskan bahwa bahan ajar adalah segala bentuk bahan yang digunakan untuk membantu pendidik atau instruktur dalam melaksanakan proses pembelajaran dikelas. Bahan ajar merupakan bagian tak terpisahkan dari pembelajaran, pemanfaatan bahan ajar merupakan segala kreatif dan sistematis untuk menciptakan pengalaman yang dapat membelajarkan peserta didik.

Sebagai pendidik, bahan ajar dalam hal-hal tertentu bisa mewakili pendidik dalam menyajikan materi pembelajaran kepada peserta didik. Jika bahan ajar yang digunakan itu dirancang dan dikembangkan secara baik, maka fungsi itu akan dapat diperankan oleh bahan ajar meskipun tanpa keberadaan penddik. Akan tetapi, dalam realita pendidikan di lapangan penulis melihat pendidik yang masih menggunakan bahan ajar yang konvensional, yaitu bahan ajar tinggal pakai, tinggal beli, instan, serta tanpa upaya merencanakan, menyiapkan dan menyusunnya sendiri. Dengan demikian, resikonya sangat dimungkinkan jika bahan ajar 
yang mereka pakai itu tidak kontekstual, tidak menarik, monoton, dan tidak sesuai dengan kebutuhan peserta didik. Agar peserta didik dapat belajar dengan baik maka bahan ajar yang digunakan harus tepat, valid, sesuai dengan gaya belajar dan perkembangan peserta didik. Dalam Pembelajaran Tematik Terpadu dimana satu tema dibuat untuk menyatukan beberapa isi pembelajaran sekaligus. Secara umum pelaksanaan pembelajaran tematik terpadu belum berjalan secara maksimal karena beberapa kendala, seperti bahan ajar yang digunakan tidak menjadikan siswa aktif. Intinya kegiatan dalam pembelajaran yang ada pada bahan ajar tidak melibatkan siswa secara aktif (Taufina \& Dahliana, 2020).

Permasalahan bahan ajar di atas dapat dilihat pada gambar berikut :

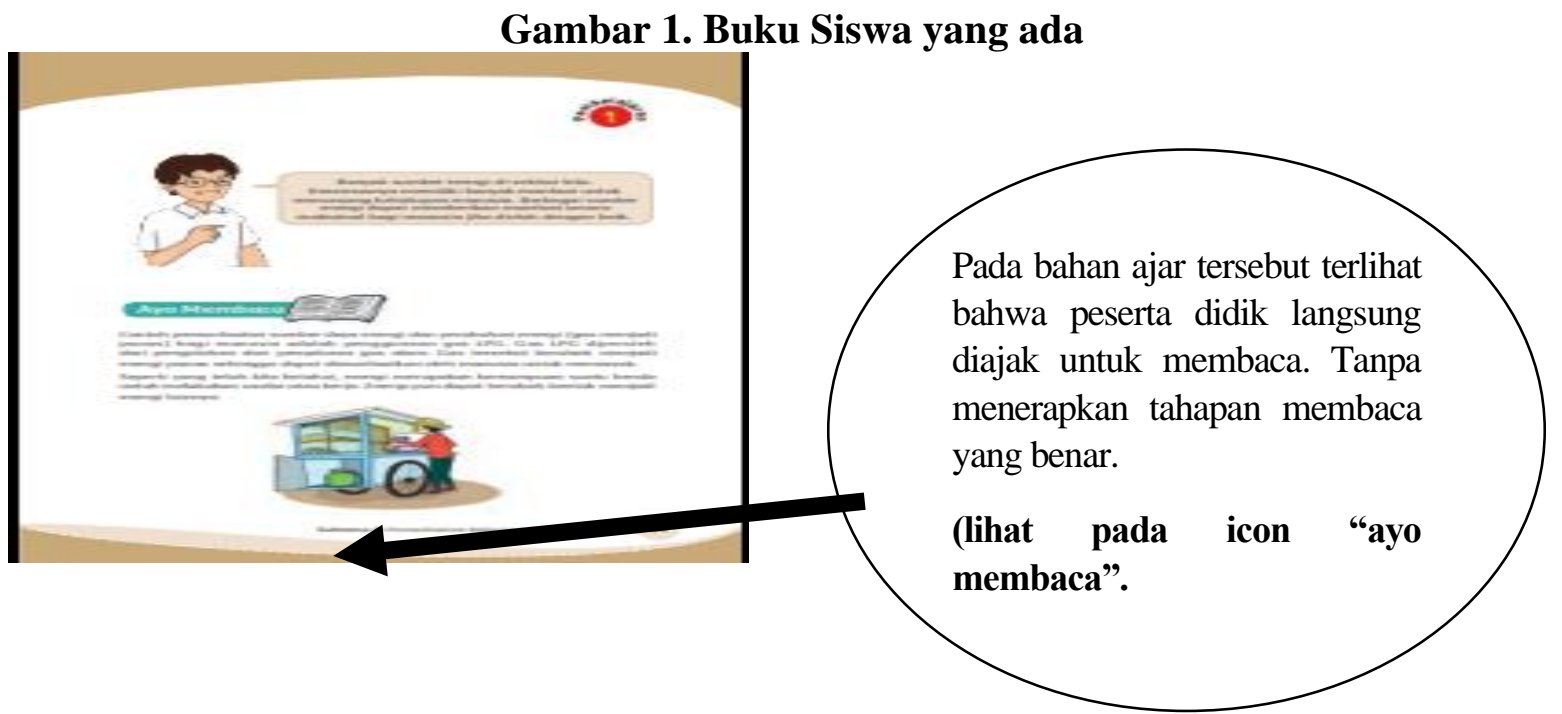

Bahan ajar yang ada pada gambar 1 di atas terlihat bahwa belum menggunakan tahapan membaca yang sesuai. Oleh karena itu, penulis merancang bahan ajar yang menerapkan tahapan membaca yang benar dengan menggunakan model yang tepat. Berdasarkan permasalahan di atas, penulis mengungkapkan beberapa cara mengatasi permasalahan yang muncul, pendidik hendaknya : (1) dituntut kreativitasnya untuk mampu menyusun bahan ajar yang inovatif, variatif, menarik, kontekstual, dan sesuai dengan tingkat kebutuhan peserta didik, (2) mengarahkan peserta didik untuk memprediksi bacaan berdasarkan petunjuk judul, petunjuk gambar, menyesuaikan prediksi mereka setelah selesai membaca, (3) memberikan evaluasi setiap selesai membaca, (4) membarengi bahan ajar yang berorientasikan dengan model pembelajaran yang sesuai dengan keterampilan membaca. Pembelajaran membaca pemahaman akan berjalan dengan baik apabila menggunakan strategi pembelajaran yang tepat yaitu menggunakan bahan ajar yang mampu meningkatkan kemampuan membaca pemahaman peserta didik. Bahan ajar yang dikembangkan berorientasi pada strategi pembelajaran yang menarik peserta didik untuk meningkatkan kemampuan 
membaca pemahaman. Berdasarkan uraian di atas salah satu cara yang dapat dilakukan untuk membaca peserta didik dalam belajar adalah dengan memberikan bahan ajar yang relevan untuk diterapkan oleh pendidik. Selain itu, model yang digunakan dalam proses pembelajaran juga sangat berpengaruh dalam meningkatkan pemahaman peserta didik dalam membaca. Salah satu model yang dapat membantu pendidik dalam proses belajar mengajar adalah menggunakan model Cooperative Script.

Menurut Istarani (2012:15) model Cooperative Script merupakan penyampaian materi ajar yang awali dengan pemberian wacana atau ringkasan materi ajar kepada peserta didik yang kemudian diberikan kesempatan kepada peserta didik untuk membacanya sejenak dan memberikan atau memasukkan ide-ide atau gagasan-gagasan baru kedalam materi ajar yang diberikan pendidik, lalu peserta didik diarahkan untuk menunjukkan ide-ide pokok yang kurang lengkap dalam materi yang ada secara bergantian sesama pasangannya masingmasing. Kelebihan model cooperative Script adalah menciptakan kondisi belajar yang nyaman bagi peserta didik dalam potensi dirinya, meningkatkan pemahaman bacaan dan kecepatan membaca, dapat mengatasi berbagai hambatan dalam membaca, menciptakan kondisi lingkungan belajar yang kondusif dalam kegiatan membaca, berisi kekayaan pengetahuan tentang membaca yang luar biasa, dan dapat memunculkan berbagai potensi yang ada di dalam diri pembaca pada saat membaca buku. Berdasarkan uraian di atas yang menggambarkan kondisi pembelajaran di Sekolah Dasar perlu kiranya dilakukan perbaikanperbaikan dan inovasi-inovasi untuk memperbaiki mutu pembelajaran tematik terpadu di Sekolah Dasar yaitu dengan membuat bahan ajar yang tepat dalam proses belajar mengajar yang mampu membantu peserta didik dalam memahami suatu konsep pembelajaran. Maka penulis tertarik untuk mengembangkan bahan ajar tematik terpadu dengan model cooperative script di kelas IV Sekolah Dasar.

\section{Metode Penelitian}

Penelitian ini merupakan penelitian pengembangan (Research and Development) untuk menghasilkan suatu produk baru, yaitu produk pembelajaran menggunakan Cooperative Script. Pengembangan bahan ajar tematik terpadu ini menggunakan model 4-D (four D model). Model ini terdiri dari empat tahap yaitu pendefinisian (define), perancangan (design), pengembangan (develop), dan penyebaran (desseminate).

\section{Hasil Penelitian}

Proses penelitian ini seharusnya dilakukan dengan 4 tahapan sesuai dengan tahap 4D yaitu define, design, develop, dan disseminate. Namun karena keterbatasan dan kondisi saat ini, maka 
penulis membatasi hanya sampai pada tahap ketiga yaitu develop. Berikut penyajian data hasil penelitian.

\section{Hasil Tahap Pendefenisian (Define)}

Pada tahap ini, dilakukan analisis kebutuhan, analisis kurikulum, dan analisis peserta didik. Hasil analisis tersebut dapat diuraikan sebagai berikut:

\section{a. Analisis Kebutuhan}

Kondisi di lapangan berdasarkan hasil studi pendahuluan, bahan ajar yang digunakan masih perlu dikembangkan karena terdapat beberapa kekurangan seperti tahapan membaca belum sesuai dengan proses membaca yang benar (yakni ada prabaca, saat baca, dan pasca baca), masih ditemukan kesalahan-kesalahan dalam penulisan dan kalimat-kalimat. Adapun hasil dari analisis kebutuhan dapat dilihat pada tabel 1 berikut ini :

Tabel 1. Hasil Analisis Kebutuhan

\begin{tabular}{|l|l|c|c|}
\hline \multirow{2}{*}{ No } & \multicolumn{1}{|c|}{ Analisis terhadap bahan ajar yang digunakan } & \multicolumn{2}{c|}{ Respon } \\
\cline { 3 - 4 } & \multicolumn{1}{|c|}{ Ya } & Tidak \\
\hline 1 & Bahan ajar yang ada sudah menggunakan model cooperative script & & $\sqrt{ }$ \\
\hline 2 & $\begin{array}{l}\text { Bahan ajar yang ada menerapkan tahapan membaca dan menulis yang } \\
\text { tepat }\end{array}$ & & $\sqrt{ }$ \\
\hline 3 & Bahan ajar yang ada membuat peserta didik tertarik untuk belajar & & $\sqrt{ }$ \\
\hline 4 & Bahan ajar yang ada masih perlu perbaikan & $\sqrt{ }$ & \\
\hline
\end{tabular}

Berdasarkan tabel 1 di atas terlihat bahwa bahan ajar yang ada masih perlu perbaikan dan dikembangkan. Cuplikan bahan ajar yang dianalisis dapat dilihat pada gambar di bawah ini:

\section{Gambar 2. Buku Siswa}

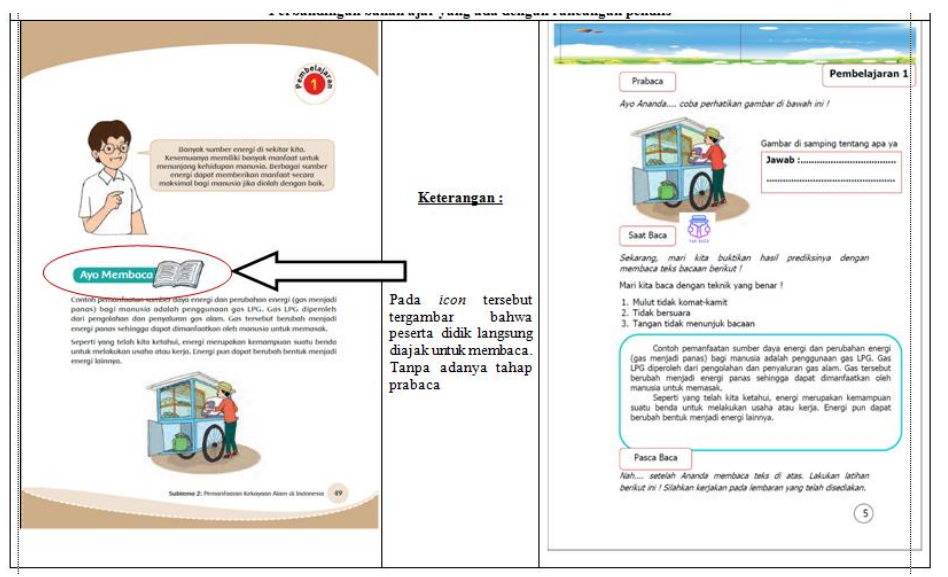

\section{b. Analisis Kurikulum}

Analisis terhadap kurikulum yang penulis lakukan adalah menganalisis kompetensi dasar yang digunakan yakni dalam penelitian ini penulis mengambil KD-KD yang ada pada tema 9 subtema 2 kelas IV. Selain itu, hasil analisis kurikulum juga dapat dilihat pada tabel 2 berikut :

\section{Tabel 2. Hasil Analisis Kurikulum}




\begin{tabular}{|c|c|c|c|c|c|c|}
\hline No & Analisis & $\begin{array}{c}\text { Sangat } \\
\text { sesuai }\end{array}$ & Sesuai & $\begin{array}{l}\text { Cukup } \\
\text { sesuai }\end{array}$ & $\begin{array}{c}\text { Kurang } \\
\text { sesuai }\end{array}$ & $\begin{array}{l}\text { Tidak } \\
\text { sesuai }\end{array}$ \\
\hline 1 & $\begin{array}{l}\text { Kurikulum yang dilaksanakan } \\
\text { sesuai dengan kurikulum yang } \\
\text { ada }\end{array}$ & & $\sqrt{ }$ & & & \\
\hline 2 & $\begin{array}{l}\text { Kompetensi yang akan dicapai } \\
\text { sesuai dengan kurikulum } 2013\end{array}$ & & $\sqrt{ }$ & & & \\
\hline 3 & $\begin{array}{l}\text { Kompetensi yang telah } \\
\text { dilaksanakan sesuai dengan } \\
\text { kompetensi yang ada pada } \\
\text { kurikulum } 2013\end{array}$ & & & $\sqrt{ }$ & & \\
\hline 4 & $\begin{array}{l}\text { Proses pembelajaran sesuai } \\
\text { dengan kurikulum } 2013\end{array}$ & & & & $\sqrt{ }$ & \\
\hline 5 & $\begin{array}{l}\text { Pembelajaran dilakukan dalam } \\
\text { bentuk tema }\end{array}$ & & & & $\sqrt{ }$ & \\
\hline 6 & $\begin{array}{l}\text { Muatan pelajaran tidak terlihat } \\
\text { terpisah }\end{array}$ & & & & $\sqrt{ }$ & \\
\hline 7 & $\begin{array}{l}\text { Proses pembelajaran dilakukan } \\
\text { dengan mengikuti pembelajaran } \\
\text { tematik terpadu }\end{array}$ & & & & $\sqrt{ }$ & \\
\hline 8 & $\begin{array}{l}\text { Kurikulum yang dilaksanakan } \\
\text { menuntut siswa yang lebih aktif } \\
\text { (student center) }\end{array}$ & & & & $\sqrt{ }$ & \\
\hline 9 & $\begin{array}{l}\text { Penilaian dilakukan terhadap } 4 \\
\text { kompetensi inti }\end{array}$ & & $\sqrt{ }$ & & & \\
\hline
\end{tabular}

Berdasarkan tabel 2 di atas tergambar bahwa adanya kecenderungan teacher

centered. Oleh karena itu, penulis mencoba mengembangkan bahan ajar yang lebih mengaktifkan peserta didik dibanding guru.

\section{c. Analisis Peserta Didik}

Karakteristik peserta didik sekolah dasar tersebut adalah senang bermain, memiliki rasa ingin tahu yang cukup tinggi, senang dengan sesuatu hal yang baru yang menarik, serta menyukai gambar-gambar dan warna-warna yang cerah. Atas dasar karakter peserta didik yang demikian, maka dilakukan penelitian yang menghadirkan sarana belajar yang berbeda dari yang digunakan sebelumnya, yaitu memiliki lebih banyak gambar yang berwarna, bahan ajar yang mengajak peserta didik belajar sambil bermain, serta mengembangkan rasa ingin tahu peserta didik yang erat kaitannya dengan perkembangan proses berpikir peserta didik. Hasil analisis terhadap peserta didik dapat dilihat pada tabel 3 berikut ini :

Tabel 3. Hasil Analisis Peserta Didik

\begin{tabular}{|c|l|l|l|l|l|}
\hline \multirow{2}{*}{ No } & \multicolumn{1}{|c|}{ Analisis terhadap bahan ajar yang digunakan } & \multicolumn{3}{|c|}{ Penilaian } \\
\hline 1 & Peserta didik sangat menyukai gambar & $\mathbf{4}$ & $\mathbf{3}$ & $\mathbf{2}$ & $\mathbf{1}$ \\
\hline 2 & Peserta didik menyukai warna yang cerah & & & \\
\hline 3 & $\begin{array}{l}\text { Peserta didik menyukai pembelajaran dengan bahan ajar yang } \\
\text { interaktif }\end{array}$ & $\sqrt{ }$ & & & \\
\hline 4 & Peserta didik menyukai kalimat yang mudah dipahami & & & \\
\hline 5 & $\begin{array}{l}\text { Peserta didik lebih senang dengan bahan ajar yang bergambar dan } \\
\text { menarik }\end{array}$ & $\sqrt{ }$ & & & \\
\hline 6 & Peserta didik sangat senang dengan hal-hal baru & $\sqrt{ }$ & & & \\
\hline 7 & Peserta didik lebih senang melihat sesuatu yang baru dalam proses & $\sqrt{ }$ & & \\
\hline
\end{tabular}




\begin{tabular}{|c|l|l|l|l|}
\hline 8 & pembelajaran (visual) & & & \\
\hline $\begin{array}{l}\text { Peserta didik lebih senang belajar dengan adanya bahan ajar } \\
\text { dibandingkan dengan mendengar ceramah guru dalam pembelajaran } \\
\text { (teacher centered) }\end{array}$ & $\sqrt{ }$ & & & \\
\hline
\end{tabular}

\section{Hasil Tahap Perancangan (Design)}

Pada tahap perancangan ini, penulis merancang bahan ajar pembelajaran tematik terpadu kelas IV Sekolah Dasar. Bahan ajar yang dirancang diperlukan untuk memudahkan pendidik dalam menyajikan pembelajaran tematik di kelas IV SD/MI dan memudahkan peserta didik untuk menyerap materi yang diajarkan pendidik. Materi pada bahan ajar yang dikembangkan mengacu pada analisis KI, KD, dan indikator yang sudah dirumuskan. Materi yang dikembangkan sesuai dengan indikator pencapaian kompetensi yang telah penulis rumuskan. Bahan ajar yang dikembangkan berupa buku siswa.

Pada setiap kegiatan yang ada pada buku siswa disesuaikan dengan tahapan model pembelajaran. Buku siswa disajikan menggunakan jenis tulisan tahoma, times new roman ukuran huruf 13 sehingga menampilkan tulisan yang sesuai dengan penulisan buku siswa SD/MI. Untuk lebih jelas, berikut disajikan bentuk rancangan buku ajar.

\section{a. Sampul}

Sampul merupakan bagian awal dari sebuah buku. Sampul yang terdapat pada bahan ajar yang dirancang haruslah menarik, agar pembaca memiliki keinginan untuk membaca isi dari bahan ajar tersebut. Agar lebih menarik ditampilkan ilustrasi yang sesuai dengan tema dan isi buku. Penggunaan ilustrasi berfungsi untuk menggambarkan isi buku dan menarik minat pembaca. Sesuai dengan pendapat Muyati dalam Indrawini, dkk (2017:1493) bahwa ilustrasi berfungsi untuk memperjelas atau mengkonkretkan informasi, membantu ingatan dan pemahaman, menarik minat dan perhatian pembaca.

Jenis huruf yang di gunakan pada sampul ini adalah Berlin Sans FB dan Cambria. Bagian atas kiri dan kanan terdapat logo tut wuri handayani dan logo kurikulum 2013. Ilustrasi gambar pada sampul bahan ajar terdapat gambar kekayaan alam di Indonesia. Hal ini menggambarkan bahwa adanya kekayaan bangsa Indonesia. Di bagian sudut kanan bawah menunjukkan bahan ajar untuk SD/MI. Dan bagian tengah bawah ada nama penulis bahan ajar tersebut. Sampul buku dapat dilihat pada Gambar 3.

\section{Gambar 3. Sampul Bahan Ajar}




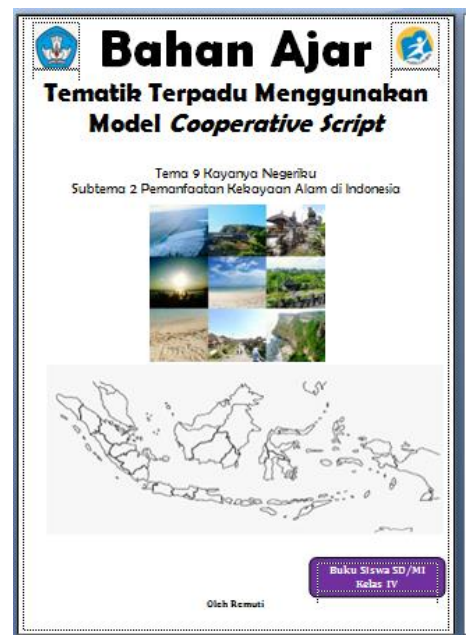

\section{Hasil Tahap Pengembangan (Develop)}

Setelah melakukan tahap pendesainan buku ajar, mulai dari merancang sampul, daftar isi, petunjuk penggunaan buku dan setiap lembar materi pada bahan ajar, kemudian barulah dilakukan tahap pengembangan (develop). Tahap pengembangan bahan ajar meliputi validasi oleh para ahli terhadap bahan ajar yang sudah dirancang, kemudian dilakukan revisi terhadap hasil validasi dari ahli.

Pada tahap validasi ini, bahan ajar yang sudah penulis rancang dan kembangkan dilanjutkan dengan kegiatan validasi oleh para ahli sesuai dengan bidang keahliannya yang terdiri dari 3 orang validator ahli. Berdasarkan hasil diskusi dan saran-saran dari validator, bahan ajar kemudian direvisi, hasil revisi ini digunakan untuk perbaikan bahan ajar yang telah dibuat dengan memasukkan segala saran yang diberikan oleh validator sehingga menghasilkan bahan ajar yang valid.

Tabel 4. Saran Validator terhadap Bahan Ajar

\begin{tabular}{|l|l|}
\hline \multicolumn{2}{|c|}{ Bahan Ajar yang dikembangkan } \\
\hline \multicolumn{1}{|c|}{ Sebelum Revisi } & \multicolumn{1}{c|}{ Sesudah Revisi } \\
\hline $\begin{array}{l}\text { 1. Logo pada sampul kurang bagus, } \\
\text { gambar kurang bagus (pecah-pecah), } \\
\text { tulisan pada sampul terlalu besar, dan } \\
\text { hilangkan warna tulisan. }\end{array}$ & 1. Logo diganti dengan yang lebih bagus, \\
\end{tabular}



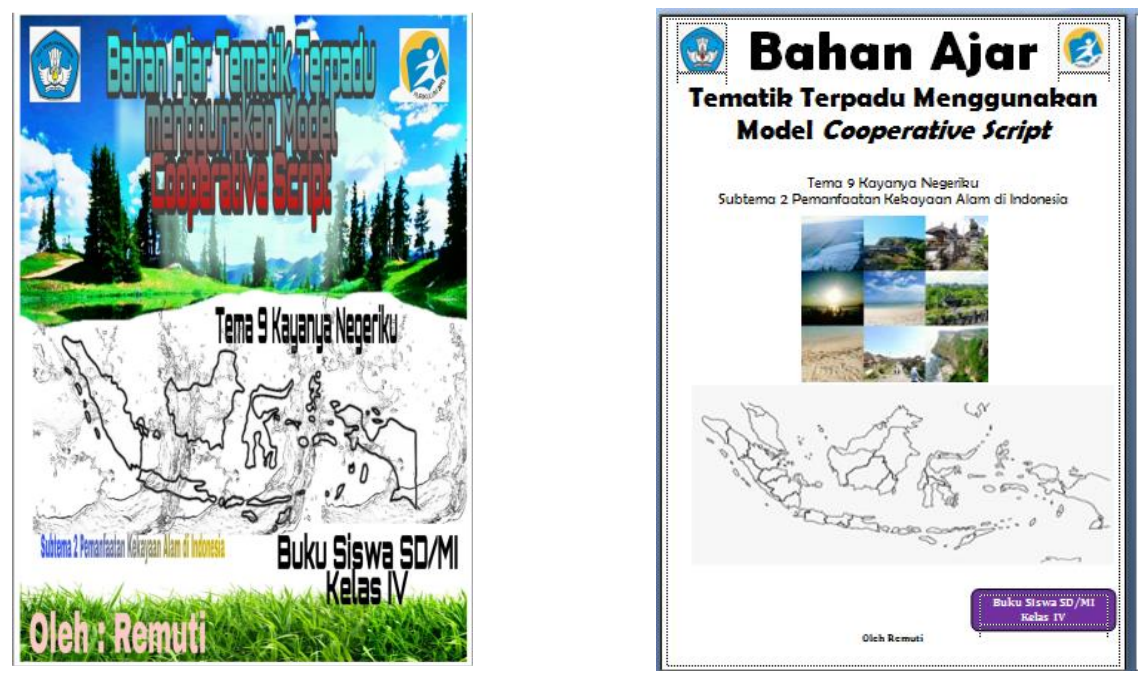

Catatan : Berdasarkan hasil saran validator, logo pada sampul terlihat lebih bagus karena warnanya sudah terkombinasi (tidak terlihat perbedaan warna yang begitu jelas).

2. Ubah jenis tulisan ke tahoma dengan ukuran 13-14. Hilangkan gambar dan tulisan pada header.

2. Sudah diganti jenis tulisan dan gambar Nomor halaman seharusnya dibagian pada header juga sudah dihilangkan.

tepi kanan bawah. Shapes diganti kotak biasa
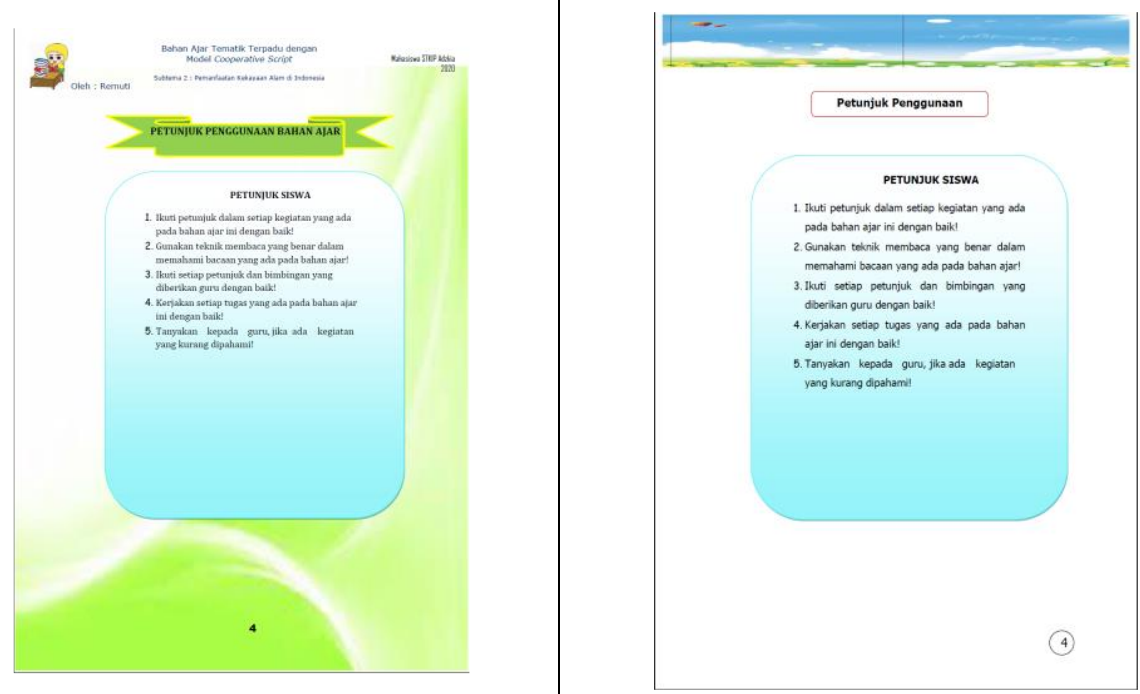

Catatan : Setelah dilihat oleh validator, bahan ajar penulis revisi dan terlihat lebih menarik dengan saran-saran dari validator.

Bahan ajar yang telah dikembangkan dikatakan valid apabila memenuhi kriteria tertentu.

Kriteria yang dimaksud seperti yang disampaikan oleh (Plomp, 2012) bahwa karakteristik dari produk yang dikatakan valid apabila terdapat merefleksikan pengetahuan (state of the art knowledge). Oleh 
sebab itu, validasi yang dilakukan terhadap bahan ajar dengan model cooperative script dalam pembelajaran tematik terpadu menekankan pada validitas isi/materi/konten, bahasa, dan desain.

Validitas isi telah dinyatakan valid oleh validator karena bahan ajar yang dikembangkan telah sesuai dengan materi yang sebenarnya pada pembelajaran tematik terpadu di kelas IV SD. Validitas bahasa dinyatakan valid apabila bahan ajar yang dikembangkan telah menggunakan bahasa-bahasa yang sesuai dengan peserta didik kelas IV SD. Validitas desain bahan ajar dinyatakan valid oleh validator apabila bahan ajar telah dikembangkan dapat menarik perhatian siswa untuk belajar. Berdasarkan analisis data penilaian validasi oleh validator, bahan ajar membaca tersebut yang dikembangkan tergolong sangat valid.

Berdasarkan hasil analisis data validasi bahan ajar oleh para ahli diperoleh persentase 87,5\% (materi) dengan kategori sangat valid, 75\% (bahasa) dengan kategori valid, dan 81,8\% (desain) dengan kategori sangat valid. Jika dilihat dari kategori yang telah dikembangkan tergolong pada kategori sangat valid. Oleh sebab itu bisa disimpulkan bahwa bahan ajar yang dikembangkan telah sesuai dengan tuntutan kurikulum. Penyajian materi telah sesuai dengan indikator yang dirumuskan dan sesuai dengan perkembangan peserta didik.

Isi bahan ajar juga telah sesuai dengan materi pembelajaran tematik terpadu di kelas IV SD. Berbagai konsep dan penjabaran tugas-tugas yang terdapat dalam bahan ajar memudahkan peserta didik memahami isi teks bacaan. Isi bahan ajar telah dapat mencapai kompetensi dasar yang dipilih. Selain itu, penggunaan bahasa dalam bahan ajar menggunakan kalimat yang sederhana dan mudah dipahami oleh peserta didik. Kalimat menggunakan bahasa yang komunikatif sehingga mudah dipahami peserta didik. Kalimat demi kalimat menggunakan ejaan yang tepat. Bahan ajar yang dikembangkan didesain dengan gradasi warna yang menarik, sehingga dapat memotivasi peserta didik untuk mengikuti proses pembelajaran dengan baik. Dengan demikian, dapat disimpulkan bahwa bahan ajar yang dikembangkan telah dinyatakan valid dan dapat digunakan dalam proses pembelajaran di kelas IV Sekolah Dasar.

\section{Diskusi}

Bahan ajar hendaknya dapat dikembangkan oleh pendidik itu sendiri agar pembelajaran dapat tercapai dan tepat sasaran. Pengembangan bahan ajar hendaknya dengan memperhatikan validitas, praktikalitas, dan efektivitasnya. Namun, pengembangan ini hanya terfokus pada validitasnya saja. Sebagaimana penelitian yang pernah dilakukan oleh Taufina dan Dahliana pada tahun 2020 yang juga mengembangkan bahan ajar untuk siswa. Selain itu, penelitian juga pernah dilakukan oleh Dahliana dan Anggraini tentang pengembangan bahan ajar (Dahliana \& Anggraini, 2021).

\section{Simpulan}

Bahan ajar secara keseluruhan berada pada kategori sangat valid. Hal ini dapat dilihat berdasarkan hasil validasi bahan ajar yang telah dilaksanakan. Hasil tersebut menggambarkan bahwa 
bahan ajar di kelas IV SD yang dikembangkan telah valid dan dapat digunakan dalam melaksanakan proses pembelajaran di kelas. Kevalidan bahan ajar dikarenakan bahan ajar yang dikembangkan telah sesuai dengan tuntutan kurikulum yakni kurikulum 2013, penyajian materi telah sesuai dengan indikator yang telah dirumuskan, serta materi telah sesuai dengan tahapan atau proses dalam membaca. Selain itu, penggunaan bahasa dalam bahan ajar menggunakan kalimat yang sederhana dan mudah dipahami oleh peserta didik. Desain bahan ajar juga telah disesuaikan dengan karakteristik dan perkembangan peserta didik. Adapun persentase kevalidan bahan ajar adalah 87,5\% (materi) dengan kategori sangat valid, 75\% (bahasa) dengan kategori valid, dan 81,8\% (desain) dengan kategori sangat valid.

\section{Daftar Pustaka}

Abidin, Y. (2014). Pembelajaran Bahasa Berbasis Pendidikan Karakter. Bandung : Refika Aditama.

Arikunto, S. (2006). Prosedur Penelitian: Suatu Pendekatan Praktek. Jakarta: Rineka Cipta.

Dahliana, D., \& Anggraini, P. (2021). Pengembangan Bahan Ajar Tematik Terpadu Berbasis Model Reciprocal Teaching Untuk Siswa Kelas IV Sekolah Dasar. Fikroh: Jurnal Pemikiran Dan Pendidikan Islam, 14(1), 79-88. https://doi.org/10.37812/fikroh.v14i1.134

Daryanto dan Dwicahyono, Aris. (2014). Pengembangan Perangkat Pembelajaran (Silabus, RPP, PHB, Bahan Ajar). Yogyakarta: Gava Media.

Depdiknas. (2006). Kurikulum Tingkat Satuan Pendidikan. Jakarta : Depdiknas.

Faisal.(2014). Sukses Mengawal Kurikulum 2013 di SD. Yogyakarta : Diandra Creative

Farida Rahim. (2007). Pengajaran Membaca di Sekolah Dasar. Jakarta:Bumi Aksara.

Huda, Miftahul. (2013). Model-model Pengajaran dan Pembelajaran. Yogyakarta: Pustaka Pelajar.

Istarani. ( 2012). 58 Model Pembelajaran Inovatif. Medan: Media Persada.

Kadir, Abd., \& Hanun, A. (2014). Pembelajaran Tematik. Jakarta : Rajawali Pers

LESTARI, A. P. (2019). Pengaruh Model Pembelajaran Cooperative Script Terhadap Hasil Belajar Tematik Peserta Didik Kelas IV SD Negeri Tulung Buyut.

Majid, Abdul. (2014). Pembelajaran Tematik Terpadu. Bandung : PT. Remaja Rosdakarya

Nurhadi. (2004). Bagaimana Meningkatkan Kemampuan Membaca?. Bandung: Sinar Baru Algensindo.

Padmadewi, Ni Nyoman., Artini, L. P., Agustini, D. A. E. (2017). Pengantar Micro Teaching.Depok : Rajawali Pers

Prastowo, Andi. (2011). Metode Penelitian Kualitatif dalam Perspektif Rancangan Penelitian. Jogjakarta: Ar-Ruzz Media.

---- (2012). Panduan Kreatif Membuat Bahan Ajar Inovatif. Yogyakarta : DIVA Pers

Putriana, R. (2019). Penerapan Model Cooperative Script untuk Meningkatkan Hasil Belajar Siswa di kelas IV SDN 8 Teluk Dalam Simeulue (Doctoral dissertation, UIN AR-RANIRY).

Ratumanan, \& Rosmiati, I. (2019). Perencanaan Pembelajaran. Depok : Rajawali Pers.

Riduwan \& Sunarto. (2012). Pengantar Statistika. Bandung: Alfabeta.

Rusman. (2015). Pembelajaran Tematik Terpadu : Teori, Praktik dan Penilaian. Jakarta : Rajawali Pres. 
Salahudin, Anas. (2015). Penelitian Tindakan Kelas. Bandung : Pustaka Setia.

Sugiyono. (2012). Metode Penelitian Kuantitatif Kualitatif dan R \& D. Bandung : Alfabeta.

Tarigan, H.G.(2016) Membaca sebagai Suatu Keterampilan Berbahasa. Bandung: Angkasa.

Taufina. (2016). Mozaik Keterampilan Berbahasa di Sekolah Dasar.Bandung : CV. Angkasa.

Taufina, \& Dahliana, D. (2020). Teaching Materials of Silent Reading With the OK5R Strategy for Elementary School Students in the Era of Revolution 4.0. 463, 59-62. https://doi.org/10.2991/assehr.k.200819.01

Theana, M. R. (2019). Keefektifan Bahan Ajar Leaflet Menggunakan Model Cooperative Script Terhadap Keterampilan Menyajikan Ringkasan Teks Eksplanasi Siswa Kelas V Sdn Gugus Perkutut Tuntang (Doctoral dissertation, Universitas Negeri Semarang).

Trianto. (2012). Model Pembelajaran Terpadu. Jakarta : PT Bumi Aksara.

Uno, Hamzah B. (2007). Model Pembelajaran Menciptakan Proses Belajar Mengajar yang Kreatif dan Efektif. Jakarta: Bumi Aksara. 